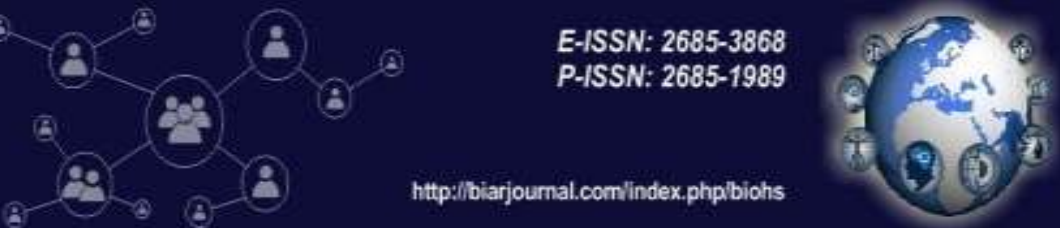

\title{
The Trucial Gulf States and Their Role in International Politics
}

\section{Muhammad Tariq Javed}

Department of International Relations, University of Peshawar, Pakistan

Email: tariqjavedup@gmail.com

\begin{abstract}
:
The study focuses on International Relation behavior of Gulf Trucial states seeking security in the wake of perceived regional and international threats. The Gulf States including and other despotic regimes in the region have been found abandoning wider regional Interest and joining Western Power and recently even Israel which is political most contested regime in the region. Gulf States are cluster of small but rich and militarily weaker states. This makes them dependent on big or influential regional and International powers. The personal and despotic family rules in Gulf state have mostly been depended for their sustenance on internationally powerful states for their defense and protection against internal and external threats. The native political movements like Muslim Brotherhood Palestinians who are supported mutually make a case of internal threats for the authoritative and despotic Gulf States Emirates. The movements in Middle East seek wider change on their agenda and the end of concentration of power The study find that personal and despotic rules ignore major political issue and their settlement to sustain their grip on power. This facilitates a short term sustenance at the cost of a bigger regional threat. This political trending of the Gulf States also entails domestic discontent which can sow seeds for future political uncertainties and discontent leading to regional security dilemma and escalated conflicts and confrontations. Paper recommends good relations conditioned with mutual reciprocity and accommodation for sustaining peace in the region to have positive impact on International peace.
\end{abstract}

\section{Keywords:}

Gulf States; International Relations; UAE; Middle East; Gulf Trucial States; Israel recognition

\section{Introduction}

The present Gulf States international behavior is consistent with their history. They tended to side with the powerful Nations is their major International Relation policy; due to their National Power imbalance. Gulf Trucial states have high strategic status and are devoid of balance security mechanism. Gulf States manifest a disproportionate National Power. They have far larger economic and strategic assets and status in the forms of hydrocarbon resources as compared to other important National Power elements like geographical depth, thin and unskilled population among major deficiencies.

The Persian Gulf has been Strategic waterway since ancient times. Abu Dhabi, Ajman, Dubai, Fujairah, Sharjah, Umm al-Qaywan and Ras al Khaima form parts of United Arab Emirate situated on the coast line of Persian Gulf., Oman, Qatar, Kuwait and Bahrain maintained their separate status and did not join United Arab Emirates (UAE); as it was called after its establishment. Iran, Iraq, and Saudi Arabia share the same Gulf coastline with Persian Gulf States. In the wider sense, all these states form part of Western Asia. These States were formed after British mandate ended over this protectorate ending their colonial status and made these states part of Indian Empire under post World War political environments. The protectorate was a measure of security as the Gulf States due to their weaker state structure 
were threatened by the other Arab states and Iran. Iran vouched for her influence in the region. A clipping of 'Times', reporting on the union of Trucial states at the time of its making (1968) describes it in these words.

"Cooperation has become necessary for the Trucial States since Britain decided to pull back its 6,000 troops and its two Hawker Hunter jet squadrons from the Persian Gulf by 1971. Arab nationalists in South Yemen have vowed to oust the sheiks, and the Egyptians, Saudi Arabians, Iraqis and Iranians are also out to extend their influence in the Gulf. Result: the Trucial sheiks are scurrying around looking for ways to protect themselves" (Time 1968).

Before this in 16 century these states were under the influence of Ottoman Empire, in those times these nomadic settlements were notorious for the piracy and maritime harassment of trade ships those passed through Persian Gulf, thus the area was known to British as 'Pirate Coast.

Since all these Gulf States are situated on the rim of Persian Gulf and guard important maritime sea lanes which give these state a special strategic value. The areas got its significance from world's best quality pearls to the modern time oil exploration that has enhanced its strategic and geopolitical role.

"The main element that unites these countries is the nature of their involvement with people and nations beyond the region. The gulf has been an important waterway since ancient times, bringing the people who live on its shores into early contact with other civilizations. In the ancient world, the gulf peoples established trade connections with India; in the Middle Ages, they went as far as China; and in the modern era, they became involved with the European powers that sailed into the Indian Ocean and around Southeast Asia. In the twentieth century, the discovery of massive oil deposits in the gulf made the area once again a crossroads for the modern world."(Halen Chapin Metz 1993).

These states have maintained their pro West leaning which now weighs more in the favor of United States of America and NATO nations in general and Israel even; to be in unison with all of these powers' foreign policies. As is the political character of the nondemocratic or despotic rulers that usually the ruler have different priority than the people who go divergent in their choices of accepting foreign influence that infringes on their domestic and regional politics. It has been observed that the non-democratic rulers disregard will of the people and place their own interest above everything. It leads to long term strategic disadvantage to national and regional interest. US and the West seems to have grasped this weakness of personal ruler in the Persian Gulf States that has become a vital tool in the hand of Western and US integrated strategies to get full control of the Western Asia and the Middle East for their extended control on the regional resources and politics and above all to safeguard strategic national interest.

This paper will be discussed role of Gulf State in the international politics. The study would also focus on the role and extent of influence of Persian Gulf States with regard to the regions of West Asian, Middle East and Persian Gulf. 


\section{Research Methods}

Mixed research method has been used. Historical references have been conflated to contemporary political development. Paper has emphasized on the special and tribal nature of the Trucial state which impacts their perception of the emerging International Political environments and their psyche in the backdrop or native environments. Reference from social media is a new way to know the political pulse at masses level, the paper reflects that too refereeing tweet to juxtapose public opinion with the element of foreign policy of the Gulf State Vis a Vis to Israel.

\section{Discussion}

\subsection{The Persian Gulf States as US Allies and its Impact on the Region}

The Trucial states of Gulf with the leading Gulf state Saudi Arabia are the main pillars of US foreign policy in the West Asian and Middle East after Israel. This is evident from their support these Gulf States of West Asia rendered to US since post World Wars and specially after the events of 9/11 starting from Iran Iraq war, going through the occupation of Iraq to the 'Arab spring', revolution or rebellion, which seems a controlled orchestration by the western powers with the US as leading player to bring in the pro West regimes and changing, what they consider, rogue and obsolete regimes; suiting to the Western and US political designs. In all these events the financial and political support by the Persian Gulf states was a crucial factor for US. NATO intervention in the affairs of Middle East under any given name. Members of the Gulf Cooperation Council (GCC) have been loyal and crucial allies of US policy in the Gulf region for over three decades. These states have been so loyal that these even undermined their own interest as is evident from the following observation.

"Perhaps more significant is that the Gulf States have even supported the United States in cases where the outcome of US intervention might threaten GCC interests. (AMEC 2011)".

Historically the role of Persian Gulf States has always been crucial to the Western and US interest and has formed a permanent feature of Persian Gulf states character. This can be weighed from the response when Iraq invaded Kuwait in the first Gulf war the US and its allies' response was overwhelming. The US forces and NATO with diplomatically manoeuvred US support of other nations sent their forces and compelled the Iraq to retreat. This has set a precedent of a series of intervention as it has resulted in crossing a psychological barrier that stops a nation to intervene physically in other nations. This paradigm has changed the whole scenario of the Middle East and rather has changed the world geostrategic. Things are not the same ever after.

Gulf States support was all out and readily available to almost all the US or NATO interventions from Afghanistan to intervention in Libya. The most blatant example was dismantling Qaddafi rule in Libya with the leading salvo by US and follow up by UK and France who was deemed a common rival by the NATO and the Gulf nations simultaneously. Qaddafi once cautioned the Arab rulers that today it Iraq and next is you. He strongly objected to the muted and silent posturing of the Arab world on the hanging of Saddam Hussain whom he call a POW. He questioned how a POW can be hanged (YouTube 2013). In the same context Dr. Mike Evans an eminent American scholar, who is a strong proponent of Zionism and state of Israel observes the way certain of the Arab rulers' fear threatened from Muslim Brotherhood movement and even Palestinians. He highlighted the dynamics of this divide beneficial to the state of Israel (YouTube, Dr Michael D Evans addresses the 
Jerusalem Post Annual Conference 2019).

This was an important strategic drive by NATO Nations in their traditional strategic arena, North Africa. In the environment of complex rivalries and terrorism emitting from the region that expands sectarian to democratic notions, deemed a threat by the undemocratic rules of the Gulf States makes a common cause where West wants contain Terrorists hub and the Gulf States need protection from popular democratic movements.

In the case of neo North African campaign of NATO nations with the strong support of USA, Qatar is a forefront state supporting, funding and supplying logistics for the NATO sponsored rebels and mercenaries, that started to oust Libyan leader Moamar Gaddafi and establish a pro West and US government in this strategically important North African state. The Libyan saga has not ended and now another round confrontation has been restarted with Franc and Turkey supporting their favourite political and militant actors in Libya. This can result in a big regional geopolitical imbalance which will clear the way for direct US and NATO control on North African's economic, political and culture leading to full control of West Asia and widely the Middle East's energy resources. The contemporary North African campaigns has its roots in Western and US strategic interest in the region. West Asian Persian Gulf state's financial and logistic support to US and Western instigated rebels or mercenaries and the North African region's opposite stance to maintain status quo has the potential of future conflict between them.

There seem an apparent desire of sustenance of personal rules in the Sheikhdoms of Persian Gulf that characterizes with this kind of political support to the West and the US interest. US rhetoric of democracy makes no sense when one looks at the opposite evidence to US supporting personal rule in Persian Gulf Sheikhdoms when the people demand to elect one chosen by them.

It is evident from the fact that when in recent times the Shia majority demonstrated for a political change in Bahrain it was crushed with full force and US's strongest and most powerful West Asian ally Saudi Arabia played active role by sending troops and military hardware to quell popular discontent in Bahrain and other Sheikhdoms. It was not possible without US's tacit support and through back door consent; however, US public stance was different and intoned with the public sentiments. US showed a mild concern for the government high handedness to the public demonstrations against the rulers; those might have been US's own carving to create leverage for better political control of these Persian Gulf states. In the wake of Arab spring, that might have the coveted consent of. International power politics players; with the leading player being the US to create a leverage that is helpful to extract West Asian and the Persian Gulf states' material and political support for NATO and US intervention seems coming to realization.

From the recent Persian Gulf wars to the America's war on terrorism and the NATO's intervention in North Africa aiming at the regime change in Libya and beyond, the role of Persian Gulf states as a 'Stepney' to the US roller coaster; will prove a long lasting impact on the West Asian and the African regions and on the relations between the Persian Gulf states and its Western and American allies and their relations within the region and wider Islamic world. 


\subsection{Future Political Role of Persian Gulf States}

Future role of Persian Gulf states vis-à-vis other West Asian states depends on the outcome of ongoing geopolitical struggle US and its allies and the amount of resistance they face.

U.S. and its allies would consolidate their influence by the use of coercive force, these state would lose their leverage and nuisance and would experience direct control by the power that be. The Trucial states of Gulf would retain their present status peculiar to their historical character.

Besides the geopolitical factors Persian Gulf states are very much alive to the economic security. They are top investors in the regions and are showing up interest to expand in the modern technology for that would enhance the economic activity in the region. This would bind it with the international interdependence phenomena, a factor that can sustain their status in the future scenarios attracting multinational corporations and world business concerns, a major economy enhancer.

According to a $\mathrm{BBC}$ business report:

"Oil-wealth has helped this region boom. But governments are realizing that they need to prepare their economies for when the oil runs out. They are trying to show the world that they are more than just one big oil field (Watson 2011)."

Small in military power and big in business makes it beyond the scope of Persian Gulf states to be at variance with the power operating in the region and working for their own interest independent of it.

Monopoly of traditional nomadic chauvinism has made any immediate opposition almost impossible however, in the case if it is sponsored by the any of the manipulating international power house, can make the blocks tremble. A very interesting question was tossed in by an online Journal 'The National' this quizzed:

"The stability pact among Qatar', Saudi Arabia and the UAE has caused robust moves in foreign policy, but what will the consequences be as the Arab Spring continues?" (Hamid, 2011).

In an article on the same page of the referred site Shadi Hamid, director of research at the Brookings Doha Center and a fellow at the Saban Center for Middle East Policy at the Brookings Institution analyses this as following:

"Domestic changes - in this case, the drive toward greater democracy - often have significant implications for foreign policy, and the Arab spring is no exception. With America's role in the region uncertain at best, the Gulf countries, for both better and worse, are going their own way. If stability is the intended destination, then they - and the rest of the region - may be in for an unpleasant surprise (ibid).

Another factor vital in observing the Trucial states' behavior is its smaller mass and inherent military weakness. That makes it understandable its' yearning to grab to powerful ally. Qatar hosts largest US military base in world. This proved a launching pad of US and NATO military operations and the biggest source of Western and US influence in the West Asia and Middle Eastern region.

\footnotetext{
1 According to the situation prevailing at the time. Recently KSA and Qatar don't have good relations due to certain disagreements indicated in the same reference.
} 
In cooperating with US and NATO the Persian Gulf states involve them even if they are not directly a party in the conflict. For example Qatar was the first to recognize the rebels fighting forces of Muamar Gaddafi vehemently supported by NATO. Qatar is supplying and facilitating military logistics to the rebels with the coveted direction of USA and NATO nations against Gaddafi government in Libya and now French support to a Libyan faction lead by a local warlord and self-acclaimed general Haftar, in the recently started struggle for power in disintegrated Libya after the British and French interventions actively supported by US. This shows the all-out behavior of the Persian Gulf state aligning with West rather than the regional nations. They feel more at ease with the real power source than nationalistic and regional sentimentalism.

The anatomy being consolidation of Sheikhs' rule of 'Trucial states' and the near danger from the rest of West Asian and Persian Gulf states whom they see with more skepticism and want to overcome this fear with farther but powerful international ally and hosting it at home to ward off any security threat.

\subsection{Sectarian Issues of Trucial States}

Iran has been a major factor in any of the Arab alliances and their leaning on US and the NATO. Besides Iran has a sectarian prejudice based in its no so good relations with rest of the Arab world owing to their predominantly 'Sunni' character. Iran exerts leadership for minority Muslim sect of Shias all over the world being the majority and biggest Shia state. This happens to be an age old friction since the political differences occurred just after the death of prophet Muhammad (S.A.W). Iran the biggest and the only Shia state which claim to be custodian of Shia sect and a self-employed sense of guarding them anywhere in the world is by default a challenge to where any Sunni majority Muslim state exist and where Shia live as minority. Bahrain is one of such state where Sunni minority rules over Shia majority. This seems a political move of British Empire that allowed such a rule in Iraq as well where Shia were in majority and were being ruled by a Sunni minority.

Such a political setting by British Empire was for the long term political objective as we see in the contemporary times that this minority ruling majority paradigm has been reversed to suit the present time political needs of Middle East by US and its allies, the previous being suitable for a different time. This is based on a simple formula of divide and rule. This is typical of the of the West and the US to choose what is best for them and disregard or take measures to contain that doesn't suit to their strategic designs guided under international power politics.

As we see in the cases of politicization of these sectarian divide, Iran is invisibly made part of NATO occupational plans where Shia card is used to seek its assistance and connivance which it never resists. We can see this evidence in the case of Afghanistan and Iraq where with the help of Shias community under Iran influence and with the tacit support of Iran NATO and USA exploited this sectarian divide for their own interest and dismantled the unwanted Taliban regime with Iran's connivance and tacit support. Presently we see the same Taliban sitting on the negotiation table with the under the US foreign policy shift or strategy.

\subsection{Normalization with Israel}

The recent move of Gulf States for the normalization of the relations is seen in the same perspective where priorities of the ruling family differs from the people's opinion. In a tweet posted by 'Middle East Eye', disowns the decision of the Bahrain for the normalization of relations with Israel and show their support for the Palestinians people. This difference of opinion can be well define as: 
"Thus the most important thing that stands out in this system and principle is freedom of expression, freedom of speech, freedom of conduct, as long as it does not interfere with the interests of the State and nation." (Irawati, 2020).

The caption reads:

"Bahrainis are standing in solidarity with Palestinians after a normalization deal between Bahrain and Israel was announced" (Twitter, 2020).

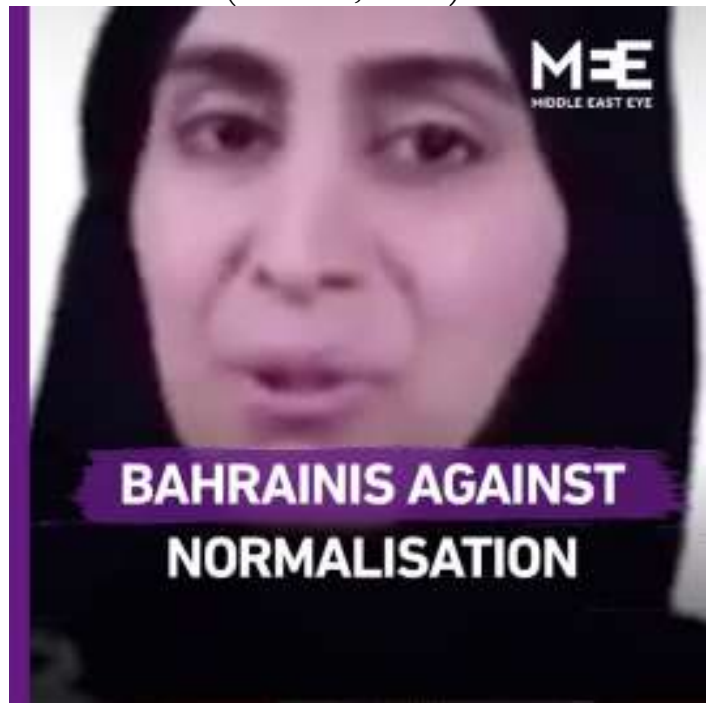

Figure 1. Middle East Eye's Tweet

Source: Twitter Media Studio ${ }^{2}$ 6:35 PM • Sep 14, 2020•

\section{Conclusion}

The Trucial states of Gulf have their peculiar tribal code and character. The tinny states have their impact on world affairs and the region. Their survival is crucial owing to regional and international threat. The Trucial Gulf states lack inherent defensive mechanism and the elements of National Power and are dependent on the powers that influences the regional politics around these states and the region. Due to internal state disequilibrium with huge strategic value being oil producing and commanding most important sea lane it leans on big powers. The Gulf States support policies of the NATO nations and US for their survival in the absence of a potent regional and alternate regional power. This leads to normalization of relations with Israel that is deems an assertive proxy and in some manner influential regional power to direct the regional policies in her favor. The weakness of Arab world and increase in Israel power and influence makes this new shift in the manifested in the character of the Trucial States of the Gulf as well make the recipe for such International behavior of the Trucial states of the Persian Gulf.

\footnotetext{
2 https://twitter.com/MiddleEastEye/status/1305560694105006080 Retrieved on 14 September 2020.
} 


\section{References}

AMEC. (2011). amec.org.za. Retrieved 2011, from http://amec.org.za/articlespresentations/the-gulf/193-potential-of-gulf-states-to-influence-us-policy

Halen Chapin Metz, e. (1993). countrystudies.us/persian-gulf-states. Retrieved September 15, 2020

Hamid, S. (2011, April 15). From the Arab Spring comes a more unified GCC.

Hamid, S. (2011, April 15). From the Arab Spring comes a more unified GCC.

AMEC. (2011). amec.org.za. Retrieved 2011, from http://amec.org.za/articlespresentations/the-gulf/193-potential-of-gulf-states-to-influence-us-policy

Halen Chapin Metz, e. (1993). countrystudies.us/persian-gulf-states. Retrieved September 15, 2020

Hamid, S. (2011, April 15). From the Arab Spring comes a more unified GCC.

Hamid, S. (2011, April 15). From the Arab Spring comes a more unified GCC.

Hamid, S. (2011, April 15). From the Arab Spring comes a more unified GCC. Retrieved September 15, 2020, from https://www.thenational.ae/from-the-arab-spring-comes-amore-unified-gcc- 1.571883

Irawati, J. (2020). Analysis the Role of Media Perspectives on General Communication and Islamic Communication. Budapest International Research and Critics Institute, Page: 2149-2157.

Time. (1968, March). www.time.com. Retrieved September 15, 2020, from Persian Gulf: Desert Merger (1968, March 1) Time. Retrieved from http://www.time.com/time/magazine/article/0,9171,941213,00.html\#ixzz1Tc5Yf5G 3

Twitter. (2020, September 14). MIddle East Eye. Retrieved from twitter.com: https://twitter.com/MiddleEastEye/status/1305560694105006080 Retrieved on 14 September 2020.

Watson, K. (2011, July 19). Middle East Business Report, BBC News. Retrieved September 15, 2020, from https://www.bbc.com/news/business-14190215

YouTube. (2013, August 31). https://www.youtube.com/watch?v=-cpiPFkL0QY. Retrieved September 15, 2020, from https://www.youtube.com/watch?v=-cpiPFkL0QY

YouTube. (2019, August 31). Dr Michael D Evans addresses the Jerusalem Post Annual Conference. $\quad$ Retrieved $\quad$ September 15, 2020, from https://www.youtube.com/watch?v=RzG88D7AU1I. 